\title{
河床形状と高水数柤度が複断面蛇行流れの權造に及ぼす影零について
}

\section{Effect of Bed Form and Roughness on Flow Structure in Compound Sinuous Channel}

\author{
石垣泰輔*・武藤裕則 $* *$ \\ Taisuke ISHIGAKI and Yasunori MUTO
}

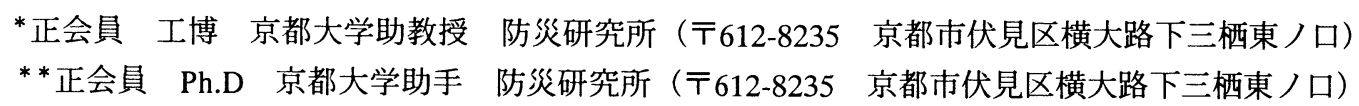

\begin{abstract}
Structure of overbank flow in compound sinuous channel is discussed based on experimental results obtained by visualization methods. Secondary flow is most important in this flow. In this paper, the influences of bed form and roughness on the flow structure are investigated by using same conditions of channel and flow except for the bed and roughness. Scouring and deposition of bed are induced by the secondary flow and vice versa. Roughness on the flood plain reduces the surrounding velocity and this reduction causes the local modification of bed. From these results the interaction between secondary flow and bed configuration can be explained.
\end{abstract}

Key Words : compound sinuous channel, secondary flow, bed form, roughness, PIV

\section{1.はじめに}

本研究で対象とする流れは, 直線水路内に設置 した低水路が蛇行する複断面蛇行流れである. 複 断面水路は, 平常時の安定した流水と洪水時の充 分な河積の確保の両立を目指して低水路と高水敷 から構成され, わが国の沖積平野の大河川ではよ く採用されている. 一般に複断面流れでは低水 路・高水敷間に流体交換が存在するが，低水路が 蛇行した場合には速度分布の歪みが大きく, その 構造はさらに複雑である.この流れの構造では 2 次流が支配的であり，主流の歪みに起因する第 1 種 2 次流と乱れの非一様性に起因する第 2 種の 2 次流の雨者が存在するここが知られている ${ }^{11-4)}$.

複断面蛇行流れに関する研究は, 主に固定床水 路を用いた流れの構造に関するものと移動床水路 を用いた河床形状に関するものに分けられる. 前 者の研究では, 相対水深 ( $\mathrm{Dr}=$ 高水敷水深 /低水 路水深）により構造が変化すること, 流れの構造 に支配的な現象が 2 次流であること, などが指摘 され, その構造図が, Willetts \& Hardwick ${ }^{1)}$, Ervine

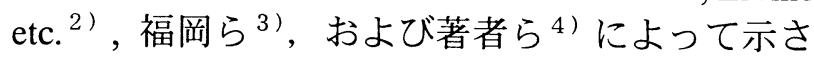
れている. 多少の違いはあるものの、共通してい る知見はつぎの 2 点である。すなわち、1)低水路 が蛇行する複断面開水路流れには、遠心力が成因 の 2 次流と、高水敷上の流れと低水路内の流れの 鈶直シアーが成因の 2 次流が存在する、2)低水路 蛇行頂部（apex）付近で発生したらせん流が高水 敷上から低水路に向かう流れに加速されながら発 達し、その後下流側の高水敷へ乗り上げる。また、 福岡ら ${ }^{3)}$ が指摘しているように、これらの構造が 水路の幾何形状や粗度分布に大きく影響されるこ とも共通した知見と考えられる。一方, 後者の移 動床水路を用いた研究は, 芦田ら ${ }^{5)}$, 福岡ら ${ }^{6)}$ お

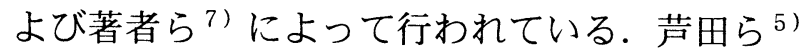
は, in-bank および over-bank の流れを対象に実験 を行い, 流れの構造や河床変動に相違が認められ ることを指摘しているものの, over-bank の流れで も相対水深が小さいため, 複断面蛇行流れ特有の 蛇行頂部の内岸側が洗掘される河床形状とはなっ (いない。一方, 福岡ら ${ }^{6)}$ は, 相対水深を広範囲 に変化させ, $\mathrm{Dr}=0.30$ 以下では蛇行頂部の外岸側 が洗掘される単断面的蛇行流れ, それより大きな 水深では内岸側が洗掘される複断面的蛇行流れに なることを指摘するとともに, 実際の河川での調 査結果と実験結果が対応することを示している. また, 著者ら ${ }^{7)}$ は 2 次流構造と河床形状との関係 について検討し，2次流が堆積域と洗掘域を形成 し，その形成された堆積域を越える流れが新たな 2 次流を形成することなどを指摘した.

本研究では, 河床形状に加えて高水敷粗度が流 れの構造に及ぼす影響を明らかにすることを目的 とした. 実際の河川に見られる帯状の高木群を模 して高水敷に透過性粗度を配置し, 低水路は移動 
表 -1 実験条件

\begin{tabular}{|c|c|c|c|c|}
\hline Case & $\begin{array}{c}\text { Main } \\
\text { channel }\end{array}$ & $\begin{array}{l}\text { Flood } \\
\text { plain }\end{array}$ & Channel & Hydraulic conditions \\
\hline $\begin{array}{l}\text { Case F } \\
\text { (Fixed bed) } \\
\end{array}$ & Fixed & Smooth & \multirow{3}{*}{ 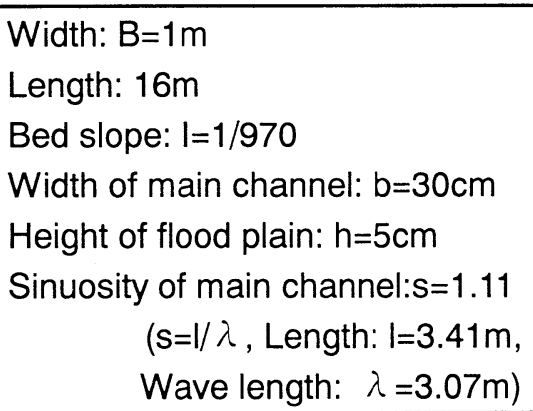 } & \multirow{3}{*}{$\begin{array}{l}\text { Relative depth : } \mathrm{Dr}=0.50 \\
\text { Depth(main channel): } \mathrm{H}=10 \mathrm{~cm} \\
\text { Depth (flood plain): } \mathrm{H}-\mathrm{h}=5 \mathrm{~cm} \\
\text { Discharge: } \mathrm{Q}=21.24 \mathrm{l} / \mathrm{s} \\
\text { Mean velocity: } \mathrm{V}=33 \mathrm{~cm} / \mathrm{s} \\
\text { Froude number: } \mathrm{Fr}=0.45 \\
\text { Reynolds number: } \mathrm{Re}=17700\end{array}$} \\
\hline $\begin{array}{l}\text { Case } \mathbf{M} \\
\text { (Movable bed) }\end{array}$ & Movable & Smooth & & \\
\hline $\begin{array}{l}\text { Case R } \\
\text { (Movable bed } \\
\text { \& Roughness) }\end{array}$ & Movable & $\begin{array}{l}\text { Rough } \\
\text { (partial) }\end{array}$ & & \\
\hline
\end{tabular}

Bed material in Case $M$ and Case $R: \mathrm{dm}=2.4 \mathrm{~mm}$, specific gravity $=1.7$

Roughness element in Case $R$ : width $=5 \mathrm{~cm}$, height $=2 \mathrm{~cm}$
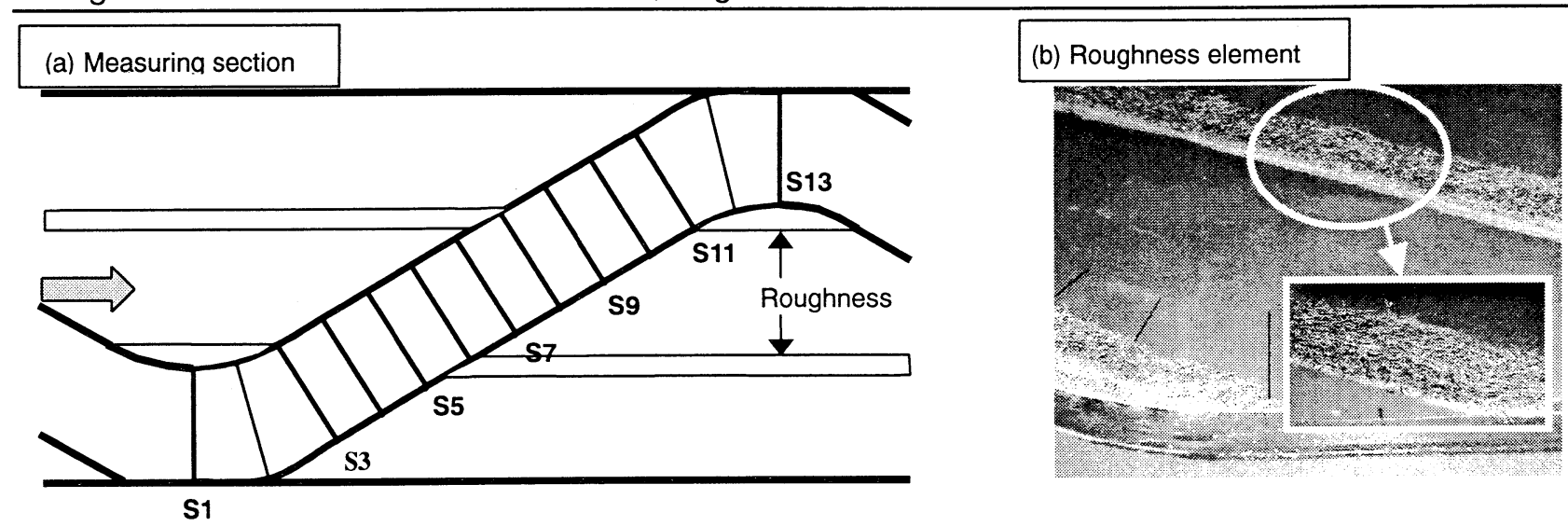

床の条件で新たに実験を行った. なお, 粗度の配 置条件によって流れの構造が大きく変化すること が予想されるが, 今回は実際の河川における高木 群の配置を参考に, 従来指摘した複断面蛇行流れ における低速域 ${ }^{7)}$ に一致させて透過性粗度を帯状 に配置した. 今回の実験結果と, 低水路が固定床 の場合 ${ }^{4)}$ および低水路が移動床の場合 ${ }^{71}$ の実験結 果を合わせて用い, 平面形状が同一の条件の下で 境界条件のみを変化させることで, 河床形状と高 水敷粗度が構造に及ぼす影響を検討した。

\section{2. 実験方法}

実験に用いた水路は，表一 1 に示すように，幅 $1 \mathrm{~m}$, 長さ $16 \mathrm{~m}$, 勾配 $1 / 970$ の直線水路内に, 幅 $30 \mathrm{~cm}$ で蛇行度（=蛇行長/蛇行波長） 1.11 の低水路を 有する複断面蛇行水路である ${ }^{8)}$. 流れの構造は, 水理条件, 水路の幾何形状, および河床と粗度の 条件に影響されることから, 本研究では, 水理条 件および水路の幾何形状を同一とし, 河床と粗度 の条件のみを変化させ, それらが流れの構造にあ たえる影響を検討することとした. 用いた条件は, 低水路および高水敷が固定床滑面のケース F, 低 水路が移動床で高水敷が固定床滑面のケース $\mathrm{M}$,
および低水路が移動床で高水敷に帯状粗度を設置 したケースRである.

移動床水路で用いた河床材料は，粒径 $2.4 \mathrm{~mm}$, 比重 1.7 のスラジライトである.これは, 掃流力 分布を検討するため, 対象とする水理条件の掃流 力と粒子の限界掃流力がほぼ同程度となる材料と して選定したものである.これにより，掃流力が 大きな領域を可視化することが可能となるととも に，実験時間が節約された。なお粒径は，砂堆な どの小規模河床形態が発生しないことを考慮して 選定した4)，7).

ケース Rで用いた粗度要素は, 表一 1 の付図(b) に示した厚み $2 \mathrm{~cm}$ のステラシートを幅 $5 \mathrm{~cm}$ の短冊 型にしたものであり, $1 \mathrm{~m}$ の水路幅を 3 等分する ように水路の両側壁より $30 \sim 35 \mathrm{~cm}$ の位置に帯状 の透過性粗度として配置した。このように高水敷 に非一様に透過性粗度を配置した理由は, 実際の 河川で高木等の高粗度域が流下方向に連なってい て帯状に存在する例があること（木津川下流部）, また前著 7)で複断面蛇行流れにおいて流れが 3 等 分され高速域と低速域が交互に存在することを指 摘したが, この低速域の出現位置と高木帯位置と の相関が高いこと，である．なおこの帯状粗度は 対象とする水理条件では完全に水没する. 

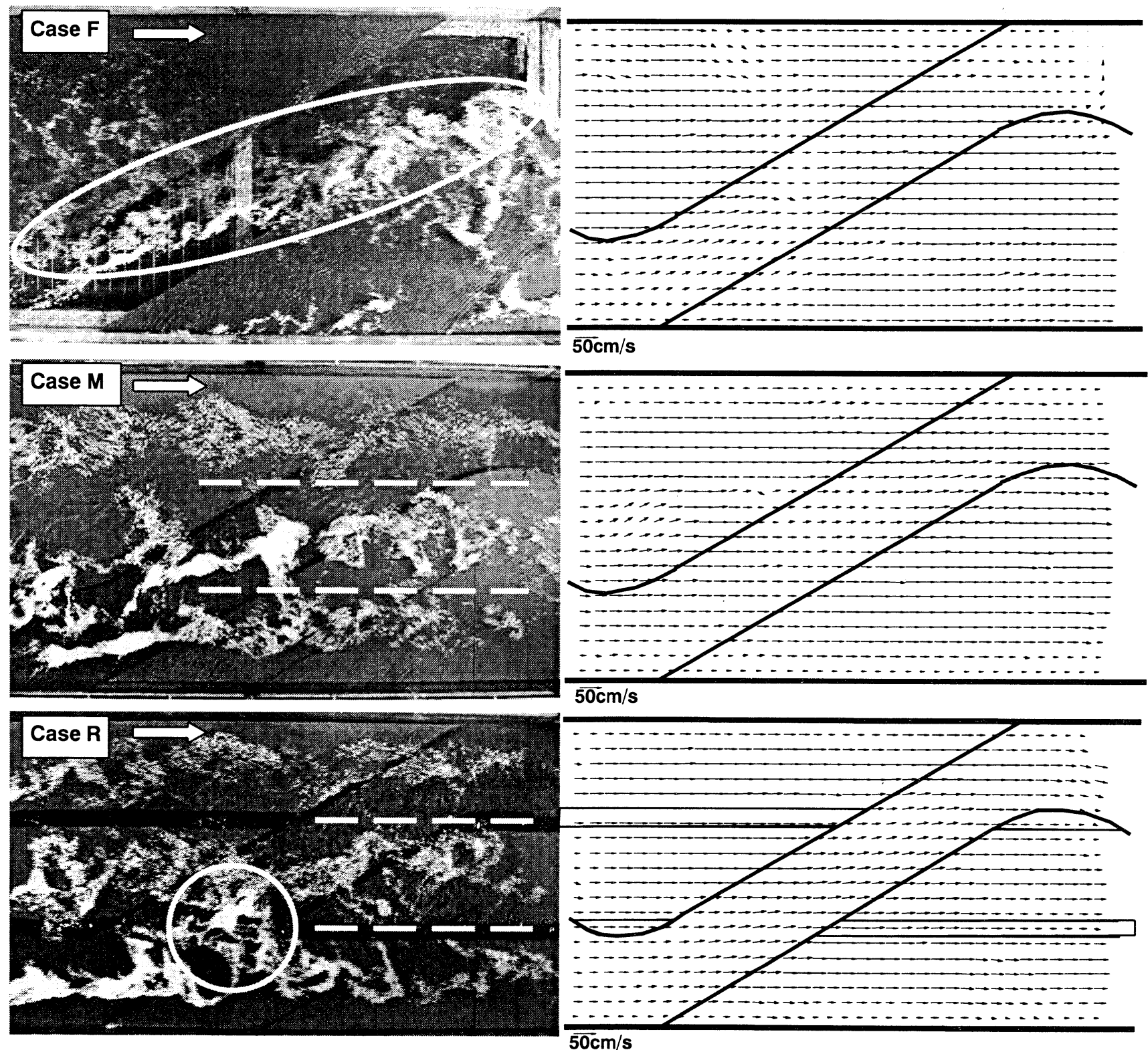

図－1 水面流況

図ー2 速度ベクトル分布

実験は,アルミ粉末を塗布したおが屑を用いた 水面流況の可視化, 掃流力分布の可視化 ${ }^{4)}$, 河床 形状計測，防水型ビデオカメラを用いた横断面流 況の可視化 ${ }^{4)}$ である. 水面流況の可視化では水路 上方よりビデオ撮影し，1/30 秒間隔で得られた 2 枚の画像に PIV 法を適用し, 可視化結果を定性的 に説明する補助として速度分布の瞬間值を得た。 PIV 法に用いたソフトは，市販のソフト

（VISIFLOW）であり，2 フレームの画像を相互 相関解析して速度べクトルを計算している．掃流 力分布の可視化は固定床水路を対象に, 河床形状 計測は移動床水路を対象に行い, 後者では超音波 河床計を用いた. 横断面流況の可視化では, 表一 1 の付図(a)に示した計測断面を対象に, 1500W の ハロゲンライトを用いて蛇行軸に沿った約 $20 \mathrm{~cm}$

幅を照明した領域の流況を，下流側約 $40 \mathrm{~cm}$ の水 中に設置したカメラ（カメラヘッドのみ：W50mm $\times$ H65.5mm $\times$ L103mm） で撮影した。なお，トレ 一サには, 粒径 $0.45 \mathrm{~mm}$, 比重 1.05 のポリスチレ ン粒子を用いた。 また, 横断面可視化結果につい ても 2 次流セルが観察される領域の可視化結果を 定性的に説明する補助として PIV 法を適用して 2 次流ベクトルの瞬間值を計算した。

なお，1．はじめにで挙げた研究より，相対水 深が大きな流れにおいて複断面蛇行流れの特徴が 顕著に見られることが分かる. 本研究では，全ケ 一スについて相対水深 $\mathrm{Dr}=0.50$ の流れを対象とし た。 また，水路下流端で堰上げ状態で実験を実施 し，対象としている区間で水深が一様になるよう に設定している. 


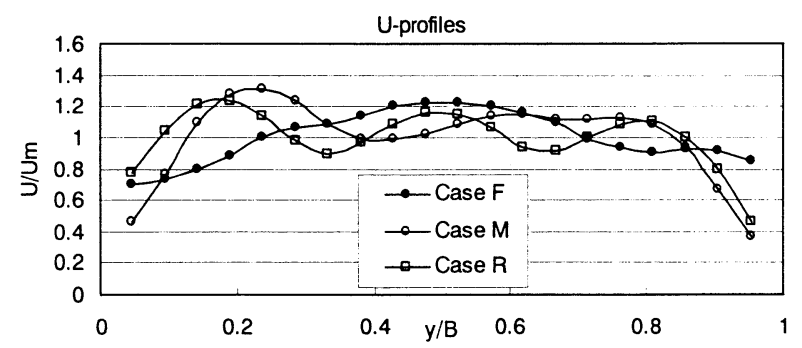

図-3 流下方向の平均速度横断分布

\section{3. 水面流況およひ速度分布}

図- 1 は水面流況の可視化結果, 図一 2 は PIV 法により得られた水面における速度べクトル分布 であり，流れは左から右である．なお，移動床の 場合, 河床変化がほぼ定常となる通水後 15 ないし 20 分の時点で可視化を行った. 水面に撒いたトレ 一サは高速部に集中するため, 高速域の位置が知 れるとともに, 3 次元構造を考慮することで流体 が下降する位置, すなわち, 2 次流セルの下降部 が分かる.このような観点より図ー 1 を見ると,

固定床水路のケース Fでは，楕円で囲んだ部分に 見られるように，上流側の蛇行頂部（以後 apex と呼ぶ）から下流側の apex にかけてトレーサが集 中し, 高水敷に乗り上げていることが分かる.こ

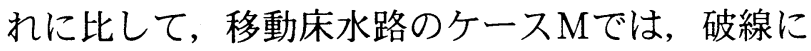
よる補助線で示すように流下方向に連なる 3 列の トレーサ集中領域が存在し, 流れの構造が変化し ていることが分かる．また，移動床で粗度を配置 したケース Rでは，3 列の集中領域と（破線によ る補助線), 帯状粗度の上流端付近での集中 (円で 囲んだ部分）が見られる。このことは, 帯状粗度 は, 流れ全体には大きな影響を及ぼさないものの, 粗度周辺に局所的な影響を及ぼしていることを示 している．図一 2 の速度分布からは，いずれのケ 一スでも, 高水敷上では流下方向の流れが卓越す るのに対し, 低水路部分では低水路内を蛇行に沿 つて流下する流れの影響を受け速度べクトルの方 向が変化していることが読みとれる.しかしなが ら可視化結果に見られるような構造を明瞭に確認 することはできない. 図一 3 は流下方向に半波長 のデー夕を平均した速度の横断分布であり, ケー スごとの差異が明らかに認められる（図中 $\mathrm{U}_{\mathrm{m}}$ は 対象領域全体の速度の平均值). すなわち, ケース Fでは, 高速域が水路中央に存在するのに対し, ケース $\mathrm{M}$ ケース Rでは水路中央と両岸の 3 力所 にあって，ケース Rでは各高速域の区分がより明 確になる，以上の結果から，河床形状により流れ の構造が変化すること, および，低速域に存在す
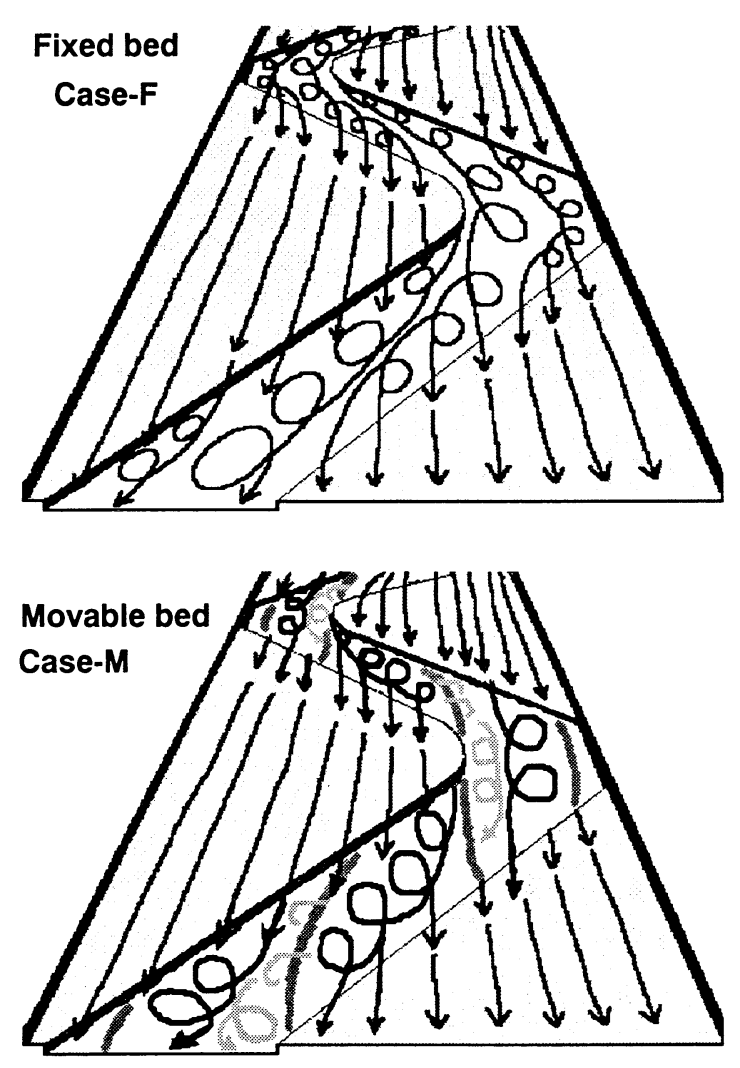

図 - 4 流れの構造

る帯状粗度により流れの構造がより明瞭に分離さ れて高速域に流れが集中することなどの点を指摘 することができる.

\section{4. 流れの構造と掃流力分布・河床形状}

前章で示した結果は流れの構造を反映したもの であり，その構造は 2 次流（らせん流）で特徵づ けられる。著者らは, ケースFおよびケースMの 構造を, 横断面流況の可視化結果などに基づいて 図ー4のように表している4，7．すなわち，ケー ス F の固定床水路においては、らせん流は apex 付近で発生し, 低水路直線部を流下するにつれて 高水敷上から低水路に流れ込む流れによって加速 されながら発達し、その後に下流側の高水敷へ乗 り上げて行く.このようならせん流の発生・発達・ 消滅の基本パターンが低水路の左右両岸で交互に 繰り返されている．前章で示した図－1の水面流 況でトレーサが集中する位置は，らせん流の沈み 込み位置に相当する. 一方, ケース $\mathrm{M}$ の移動床水 路では, 上述したらせん流の発生・発達・消滅の 基本パターンは変わらないが, 流れに応じて形成 される河床形状, 特に堆積域（図一 5 中段参照） が領域を分断し, 基本パターンは堆積域によって 分断された湾曲部内および蛇行直線部（以降 crossover 部と呼ぶ）内でそれぞれ完結する。複断 


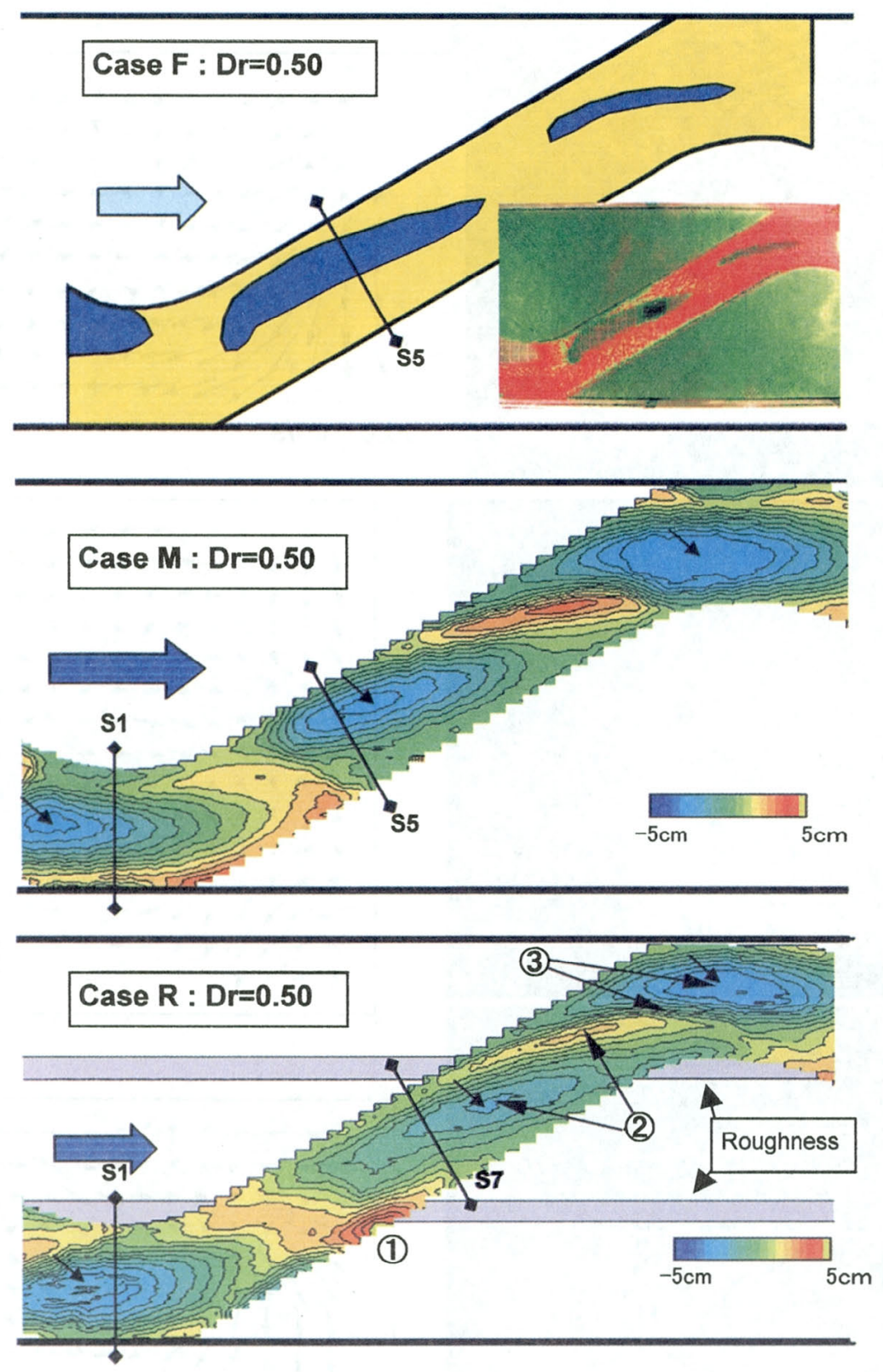

図一 5 掃流力分布および河床形状

面水路全体としては, 結果的に水路中央部付近と 左右側岸沿いに分離された 3 列の構造が形成され る. また, 低水路内では堆積域を越える流れが生 じ, その剥離域に新たな 2 次流が形成される。 こ の新たな 2 次流は上述のらせん流とは逆向きの回 転を持つため，相互に干渉しあい勢いを強めなが ら発達する。なお、図中、低水路内の矢印付き実 線はらせん流を、薄い矢印付き実線は剥離域に新 たに形成される 2 次流を、高水敷に乗り上げた流 れを矢印付きの線で表している。

以上の構造は, 低水路底面の掃流力分布に影響 を与え, 移動床の場合は洗掘・堆積現象を引き起 こす，そこで，図ー 5 に示した結果に基づいて, 流れの構造と掃流力分布について検討する.なお,
ここに示した河床形状は，形状の時間変化が小さ くなった時点で通水を停止した後に計測した結果 である，上段の図は，ケース F（固定床水路）に おける掃流力分布の可視化結果 ${ }^{4}$ であり，参考の ために実画像を併示している。低水路内のブルー に着色した部分（添付の画像では水路の底面が露 出した部分) が河床材料が掃流された領域であり, 蛇行低水路の直線部 (crossover 部) と湾曲部の apex 付近の 2 箇所に見られる。これと図 -4 で示した 流れの構造を比較してみると, 河床材料が掃流さ れた領域とらせん流により高速流体が底面まで輸 送される領域がほぼ一致し，この高速流体によっ て相対的に大きな掃流力が作用していることが分 かる.また，そのような領域が crossover 部と apex 

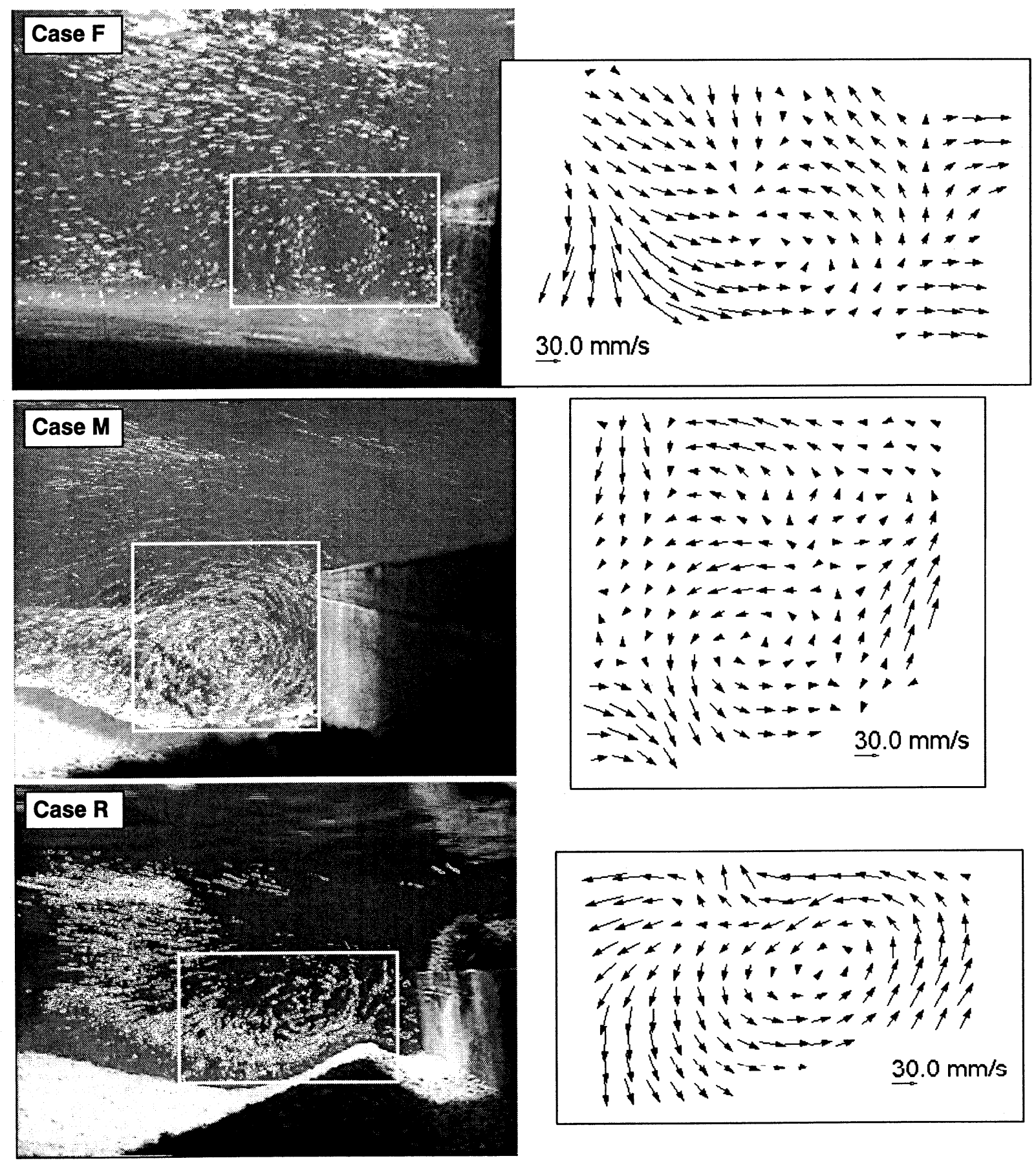

図 - 6 Crossover 部の 2 次流セル

付近とに分離して存在することから，らせん流が 複列化していることが知れる.この現象は, 中段 に示した移動床水路での結果（ケースM）におい て，より明確にみられる. 移動床の場合には, 河 床材料の輸送が伴うため, 洗掘域から輸送された 粒子が堆積域を形成し，それにより流れの構造が 分離される. このケースでは, 蛇行部内岸側が洗 掘され, 福岡ら ${ }^{6)}$ の結果と一致する. この結果に 比べ, 下段のケース Rでは, 洗掘域および堆積域 の形成は同様であるが, いくつかの相違点がみら
れる. すなわち, 帯状粗度が有る場合, (1)右岸側 高水敷上の粗度帯上流端では, その上流側の低水 路右岸の洗掘域から供給された河床材料が停止し て堆積する, (2)crossover 部の低水路左岸側から発 達する洗掘域と堆積域が下流側にシフトする, (3) その結果, apex 付近ではテラス状の堆積域が形成 され, 洗掘域は湾曲外岸部へと移動する（各説明 文の番号は図中の○付番号で示した位置を参照し ている).これらの現象は, 帯状粗度周辺およびそ の上・下流側の速度が低減して掃流力が小さくな 


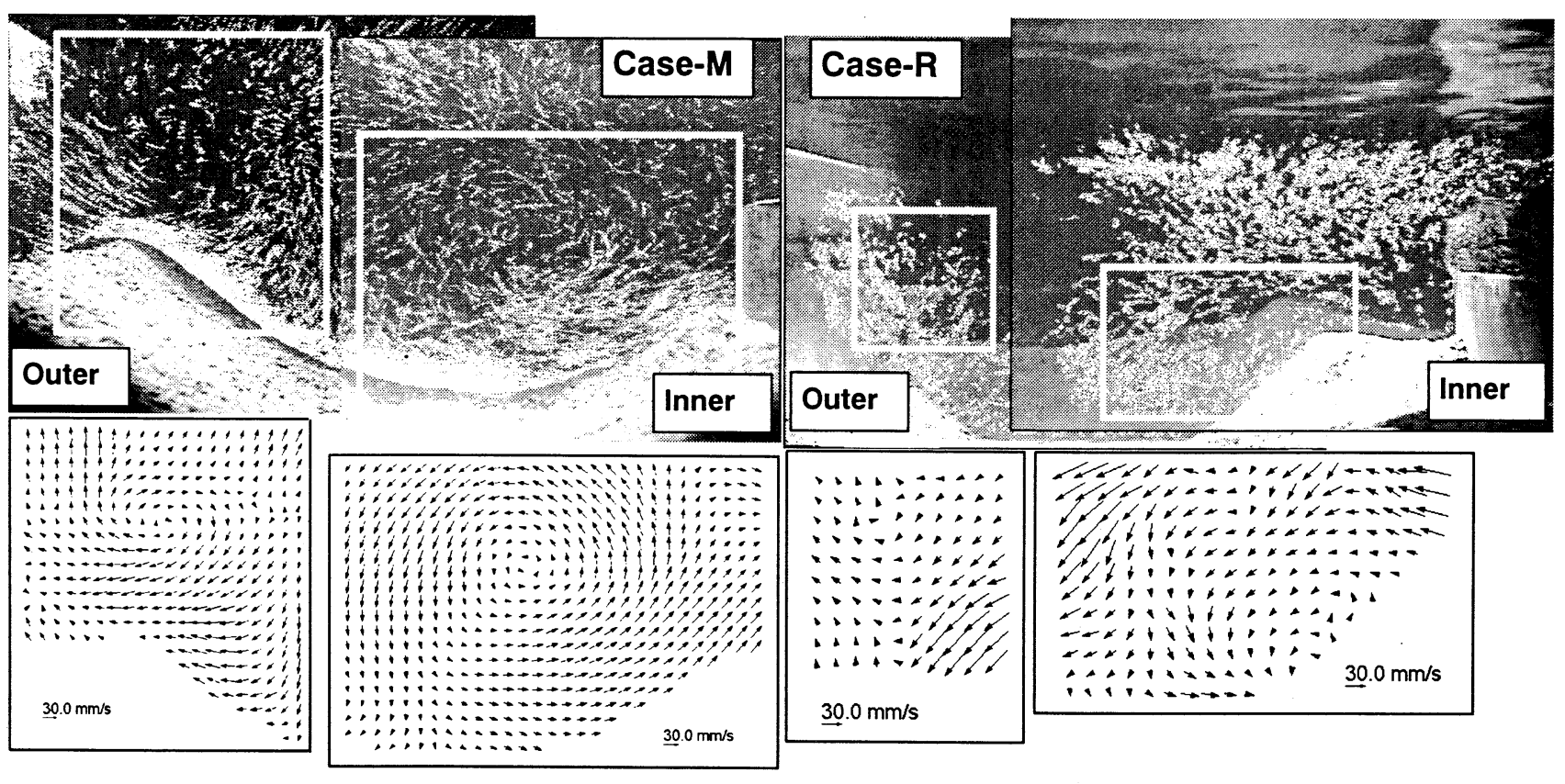

図-7Apex 付近の 2 次流セル

るために起こるものと考えられる.この結果より, 流れの構造を検討する際には, 局所的な高粗度域 の影響を考慮する必要のあることが指摘される.

\section{2 次流セルの特性}

図一 4 の構造が示すように, 複断面蛇行流れで は 2 次流が流れの構造を特徵づける支配的な現象 である. 以下では 2 次流が最も発達する crossover 部と apex付近で行った横断面可視化とPIV 法によ って得られる 2 次流べクトルの計算結果を用い, 2 次流セルの特性について検討する. ただし， 3 次元構造を有する 2 次流をビデオ撮影によって得 られる 2 次元画像から計算した速度べクトルを用 いて検討することには定量的な問題が残る。しか しながら, 動画で観察される 2 次流の挙動と矛盾 しない程度の限られた領域を選択することにより， 2 次流セルの回転方向, 大きさなどの定性的な検 討が可能であると判断し, PIV 法による 2 次流べ クトル計算結果を用いて検討を行うこととした.

図一6は，crossover 部における横断面可視化結 果と PIV 法による 2 次流ベクトル計算結果（可視 化画像の白枠内を対象）である. 前述したように 可視化は視点（カメラ）を下流側において行って おり，したがって画像右側に上流側（低水路左岸 側）高水敷, 左側に低水路中央部が撮影されてい る. なお, 可視化画像は連続した 3 フレームにお ける粒子を抽出して重ね合わせたものである．ま た可視化断面位置は, 図ー 5 に示したように, 大 きな掃流力が作用して洗掘域が形成される領域で
あり, ケース $\mathrm{F}$ とケース $\mathrm{M}$ は S5 断面, ケース $\mathrm{R}$ では S7 断面である. 前章で述べたように, ケー ス Rでは帯状粗度の影響により crossover 部の洗 掘域と堆積域が下流側に移行するため,このケー スでは断面 S5より下流側の S7 断面での結果を用 いて比較することとした. 図より，いずれのケー スのおいても, 反時計回りの 2 次流セルの存在と, 低水路中央側の底面に向かう強い流れの存在が明 確に認められる. 2 次流セルは, 強い下降流と弱 い上昇流で形成されている．この強い下降流は, 高水敷上の流れが高水敷先端で剥離して低水路内 に潜り込むために形成されるものであり, セルの 回転を加速するとともに, 底面に衝突して大きな 掃流力を発生させて河床を洗掘する. また, 移動 床では, 洗掘された粒子が 2 次流セルによって洗 掘域の斜面に沿って輸送されて下流側に堆積域を 形成する．ケース Mに比べて帯状粗度があるケー ス Rの 2 次流セルは, 扁平になるとともに低水路 側岸より離れた位置に形成される.これは, 帯状 粗度の影響による周辺の速度低減効果により低水 路左岸側に沿って堆積域が形成されるため, らせ ん流が十分発達できないことが要因と考えられる.

図一 7 は, apex 近傍の横断面可視化結果と 2 次 流ベクトル計算結果をケース $\mathrm{M}$ とケース Rについ て示したものである. 可視化断面は, 図一 5 に示 した S1 断面を挟む区間である. また, 低水路は 図の右奥よりこの断面に達し，右手前に続いてい る. 図のようにケース Rの河床形状は, 前章でも 述べたように, crossover 部のらせん流によって形 成される洗掘域と堆積域が下流側に移行するため, 
apex の内岸側には図にみられるようなテラス状 の堆積域が形成され，洗掘域が外岸側に寄ってい る.このようなテラス状の堆積域の形成には, apex に設置した帯状粗度の影響で周辺の速度が低減さ れて粒子の輸送が緩慢になることも影響している。

図より,いずれのケースにおいても, 内岸側 (図 の右側：Inner と表示）では反時計回りの 2 次流セ ル, 外岸側では時計回りの 2 次流セルが存在する. ケースRにおける内岸側の 2 次流セルは, 堆積域 の頂部で剥離した流れが洗掘域斜面に形成するも のである.これに対し，ケースMで見られる内岸 側の大きな 2 次流セルは, 上流側に形成された堆 積域を越えた流れによって形成された 2 次流セル が，この断面に達するまでに大きく発達したもの である，一方，いずれのケースにおいても，外岸 側のセルは, 上流側の高水敷から低水路に流入し た流れによって形成されたものであり，この断面 に達するまでに内岸側の強いセルによって外岸側 へと押し出され, 下流側の高水敷に乗り上げて行 く, と言う過程をたどる.

\section{6. おわりに}

本研究は, 同一の平面形状を有する複断面蛇行 水路における同一の水理条件の下で, 低水路の河 床条件と高水敷の粗度条件のみを変えた実験で得 られた結果を用い,これらの条件が流れの構造に 与える影響について検討したものである. 得られ た主な結果をまとめると以下のようである.

1) 固定床水路を用いたケース $\mathrm{F}$ と移動床水路を

用いたケース Mで得られた結果の比較より，2 次流によって河床に洗掘域と堆積域が形成さ れ,その河床形状によって 2 次流構造が変化す る, という流れの構造と河床形状との相互作用 が確認された。

2 ）ケース $\mathrm{M}$ と移動床水路で高水敷状に帯状粗度 を配置したケース Rの比較より,帯状粗度の影 響は流れ全体には及ばないものの, 帯状粗度の 周辺に形成された低速度域の影響により, 周辺 に堆積域が形成される. その結果, crossover 部で形成される洗掘域と堆積域が下流側に移 行するとともに下流側の apex まで達し, テラ ス状の堆積域が形成される.これにより, apex の洗据域が外岸側に移動する.

3 ） crossover 部の 2 次流セルは，いずれのケース においても同様に形成されるが,ケース Rでは 帯状粗度周辺の速度低減域の影響を受け, 他の ケースに比べてセルが扁平になるとともに, 低 水路側岸より離れた位置に形成される. 一方, apex 付近におけるケース Rの 2 次流セルは,
ケース Mに比べて強さやスケールが小さくな る.これは, 帯状粗度の存在で変化した河床形 状の影響である.

4）以上の結果より, 高水敷に設置した帯状粗度 は, 局所的な粗度の変化にもかかわらず, 河床 形状や流れの構造に影響を及ぼすことが知れ た.このことは, 複断面蛇行流れを検討する上 で, 局所的な高粗度域の影響を考慮する必要の あることを意味している。

5 ）横断面可視化結果に PIV 法を適用する場合, 2 次流セルが安定して観察される領域に限定 すれば,動画像での 2 次流観察結果と矛盾しな い結果が得られ, それによる定性的な検討が可 能であることが確認された.

本研究で対象とした流れは，1章で述べたよう に，蛇行度などの水路幾何形状の影響を受けるこ とが知られており，その影響について検討するこ とが今後の課題である.

\section{参考文献}

1) Willetts,B.B. and Hardwick,R.I. : Stage dependency for overbank flow in meandering channel, Int. Conference on River Flood Hydraulics, pp.45-54, 1993.

2) Ervine, DA, Willets, BB, Sellin, RHJ and Lorena, M. : Factors affecting on conveyance in meandering compound flows, J. Hydraulic Eng., Vol.19, No.12, pp.1383-1399, 1993.

3) 福岡捷二、大串弘哉、加村大輔、平生昭二 : 複 断面蛇行流路における洪水流の水理、土木学会 論文集、No.579、II-41、pp.83-92、1997.

4)石垣泰輔, 武藤裕則, 澤井健二 : 複断面蛇行開 水路流れの 2 次流構造と掃流力分布に関する実 験的検討, 土木学会, 水工学論文集, 第 43 巻, pp.329-334, 1999.

5)芦田和男, 江頭進治, 劉丙義, 滝口将志 : 蛇行 低水路を有する複断面流路における流れの特性 と河床変動機構, 京都大学防災研究所年報, 第 32 号 B-2, pp.527-551, 1989.

6)福岡捷二, 小俣篤, 加村大輔, 平生昭二, 岡田 昭治 : 複断面蛇行河道における洪水流と河床変 動, 土木学会論文集, No.621/II-47, pp.11-22, 1999.

7) 石垣泰輔、武藤裕則 : 複断面蛇行開水路流れの 2 次流構造と河床形状に関する実験的検討、水 工学論文集、第 44 巻、pp.855-860,2000.

8) 石垣泰輔、武藤裕則：緩やかに蛇行する低水路 を持つ複断面開水路流れに関する実験的検討、 水工学論文集、第 42 巻、pp.943-948,1998.

（2000 年 4 月 21 日受付） 